\title{
The Effects of Personality Traits on Subjective Well-being and Behavioral Intention Associated with Serious Leisure Experiences
}

\author{
Jang Heon HAN ${ }^{1}$
}

Received: February 10, 2020 Revised: March 15, 2020 Accepted: March 31, 2020

\begin{abstract}
The study examined how the personality traits, manifested during serious leisure experience, i.e., experiences that involve the acquisition of special knowledge or techniques and the participation required to achieve the expertise necessary to express them. This study also investigated how such subjective well-being affected behavioral intention, specifically, the intention to use the same leisure facilities again and to spread this information to acquaintances by positive word of mouth. A survey was administered to 727 research subjects selected from pre-registered panels enrolled by an online research organization. The main constructs examined in this study were measured on 5-point Likert scales using multiple items. A structural equation model was employed to verify the proposed conceptual model and the relationships among variables. The results revealed that, of the personality traits, participants high in extraversion, openness to experience, and agreeableness felt high levels of life satisfaction and positive affect, i.e. a sense of subjective well-being. Second, users who felt a high level of subjective well-being, specifically, high life satisfaction and positive affect, also indicated a high level of behavioral intention. Finally, the academic and practical implications and limitations of the study, as well as future research plans involving the personality traits underlying serious leisure experiences are discussed.
\end{abstract}

Keywords : Personality Traits, Subjective Well-being, Behavioral Intention, Serious Leisure Experience

JEL Classification Code : L83, M31, N35

\section{Introduction}

The leisure industry has undergone rapid growth since World War II and is forecast to continue growing based on social and industrial development (Unger \& Kernan, 1983). The South Korean tourism and leisure industry, including hotels, ski resorts, golf courses, and theme parks, has grown significantly, by about $25 \%$ in five years, from a scale of w20 trillion in 2011 to w25 trillion in 2016 (Tourism \& Leisure Industry Skill Council, 2018). People want to create more meaningful and happier memories rather than simply functional services. Positive feelings such as excitement and joy are the goal of consumer behavior, and customers who

\footnotetext{
${ }^{1}$ First Author and Corresponding Author. General Manager, AQ Marketing Team, Hanwha Hotels \& Resorts, Korea. [Postal Address: 50, 63-ro, Yeongdeungpo-gu, Seoul, 07345, Korea] Email: cooljanghun@naver.com

(c) Copyright: The Author(s)

This is an Open Access article distributed under the terms of the Creative Commons Attribution Non-Commercial License (http://Creativecommons.org/licenses/by-nc/4.0/) which permits unrestricted noncommercial use, distribution, and reproduction in any medium, provided the original work is properly cited.
}

experience positive affect by means of a positive experiences will continue to pursue the same positive experiences in the future (Richins, 2007).

People's interest in subjective well-being, as reflected in overall life satisfaction and happiness, continues to increase (Ryan \& Deci, 2001). The relationship between experience and subjective well-being, specifically happiness, can be explained by a temporal stage model (Diener, Scollon, \& Lucas, 2009). Pleasant and highly immersive experiences have an immediate effect and are stored in affective memory. People experience happiness by frequently drawing on this affective memory. By sensitively accepting pleasant stimuli, extroverted people easily experience positive affect (Larsen \& Ketelaar, 1989; Rusting \& Larsen, 1997; Uziel, 2006). Thus, people are predicted to achieve optimal experiences through serious leisure experiences such as skiing, and to reveal their happiness by experiencing a high level of flow (Csikszentmihalyi, 1990). In addition, each person experiences happiness differently, and these differences are affected by internal qualities such as personality and self-esteem. In particular, happiness is closely related to personality traits (Deneve \& Cooper, 1998). Personality traits 
have been classified into five factors, namely agreeableness, conscientiousness, openness to experience, neuroticism, and extraversion, referred to as the personality traits (McCrae \& Costa, 1991).

Studies establishing causal relationships between personality traits and subjective well-being by applying personality traits as antecedents have taken a variety of forms (Anglim \& Grant, 2016; Gutiérrez, Jiménez, Hernández, \& Pcn, 2005; Hayes \& Joseph, 2003; Henning, Hansson, Berg, Lindwall, \& Johansson, 2017; Meléndez, Satorres, Cujiño, \& Reyes, 2019; Zhai, Willis, O'Shea, Zhai, \& Yang, 2014). However, most of these studies have selected a particular age range or subject group, such as retired adults, workers, or elderly people. Studies that identify the mechanism underlying personality traits' roles in the formation of subjective well-being among people engaging in serious leisure activities have been absent. Studies that have disclosed the effects of personality traits on subjective wellbeing in situations involving serious leisure experiences are important because, unlike existing studies on general situations, situations involving serious leisure experiences involve different personality traits that have different effects on subjective well-being. Dispositional traits, such as extraversion, which helps in maintaining warm-heartedness and good interpersonal relationships, or neuroticism, seen in high levels of compulsion or inferiority, affect hedonic balance, which forms the basis for subjective well-being (Schimmack, Radhakrishnan, Oishi, Dzokoto, \& Ahadi, 2002). Furthermore, previous research has shown a causal relationship between subjective well-being and behavioral intention for a variety of experiences, and a similar effect is predicted for the relationship between subjective wellbeing and behavioral intention related to serious leisure experiences.

In summary, the purpose of the present study was to determine how the personality traits affect the subjective well-being of skiers during serious leisure activities at ski resorts. Second, the study examined how skiers' subjective well-being affects behavioral intention. The results will have implications for the field of tourism and leisure studies and practical implications for relevant work in the field.

\section{Review of Literature and Hypothesis}

\subsection{Personality Traits and Subjective Well-being}

The present study attempted to reveal which of the personality traits directly affect subjective well-being during serious leisure experiences and to identify the underlying causal mechanism so as to understand why such a consumer behavior occurs. Serious leisure experiences are those that involve the acquisition of special knowledge or skills and the participation required to achieve the expertise to express them (Stebbins, 1992). These are the activities systematically performed by hobbyists, amateurs, and volunteers who pursue them with the aim of achieving sufficient expertise (Stebbins, 1982, 1992). Comprehensive research is underway in the field of leisure sports and tourism, with research undergoing further segmentation as the field expands to incorporate adventure tourism, including paragliding, hang gliding, surfing, and other outdoor recreation activities that place importance on building expertise.

Furthermore, personality has been defined by scholars in different ways depending on their perspectives. Hodgetts and Fountain (1987) referred to personality as the stable characteristics or tendencies used to distinguish similarities and differences among people. Judge and Bono (2000) referred to personality as the characteristics distinguishing one person from another in various situations, as well as patterns of behavior, including emotions. Dirks and Ferrin (2002) refer to personality as a fixed part of an individual that allows them to behave in a consistent pattern. Personality is said to be affected by genetic factors, such as DNA, as well as by cultural customs. The model of personality traits, one of the theories that most clearly defines personality traits, was developed by joint factor analysis (Costa \& McCrae, 1991). Agreeableness is expressed through of trust, straightforwardness, and altruism, among other traits. Extraversion comprises warmth, sociability, activity, and related traits. Openness to experience is manifested in imagination, aesthetics, openness to feelings, and openness to actions, among other qualities. Conscientiousness entails competence, order, dutifulness, achievement striving, and deliberation, along with related qualities. Neuroticism is reflected in anxiety, hostility, depression, vulnerability, and related traits (John, 1990). According to instrumental theory, personality traits have direct effects on actions or circumstances, which in turn affect subjective well-being (Heller, Watson, \& Ilies, 2004). In addition, according to temperament theory, personality traits affect subjective wellbeing as a result of emotional reactivity and the effect of cognitive processing over emotional information (Diener, Oishi, \& Lucas, 2003).

Kahneman and Krueger (2006) argued that leisure activities have great effects on subjective well-being and that daily life activities, such as shopping, fail to affect subjective well-being. Costa and McCrae (1992) introduced the personality traits and examined their correlation with affective variables. Extraversion is positively correlated with positive affect, whereas neuroticism is correlated with negative affect. DeNeve and Cooper (1998) showed that extraversion was positively correlated and neuroticism was negatively correlated with life satisfaction. In their study on workers in five Chinese cities, Zhai et al. (2014) reported that extraversion and conscientiousness had a positive effect on subjective well-being, whereas neuroticism had a 
negative effect. Meléndez et al. (2019) suggested in their research on elderly people in Columbia that extraversion, openness to experience, and conscientiousness had positive effects on subjective well-being, while extraversion and conscientiousness had positive effects on life satisfaction. In contrast, neuroticism appears to have a negative effect on life satisfaction. Based on this prior work, the present study predicted that the personality traits would affect subjective well-being during serious leisure experiences. The specific hypotheses of this study were:

H1: Personality traits have a significant effect on subjective well-being.

H1-1: Extraversion has a positive effect on life satisfaction

H1-2: Openness to experience has a positive effect on life satisfaction

H1-3: Conscientiousness has a positive effect on life satisfaction

H1-4: Agreeableness has a positive effect on life satisfaction

H1-5: Neuroticism has a negative effect on life satisfaction

H1-6: Extraversion has a positive effect on positive affect

H1-7: Openness to experience has a positive effect on positive affect

H1-8: Conscientiousness has a positive effect on positive affect

H1-9: Agreeableness has a positive effect on positive affect

H1-10: Neuroticism has a negative effect on positive affect

\subsection{Subjective Well-being and Behavioral Intention}

Subjective well-being is the subjective sense of happiness experienced by an individual (An \& Zhang, 2019). Such happiness is remembered and experienced differently depending on how people accept the things that have happened to them during their lifetime (Lyubomirsky \& Ross, 1997; Lyubomirsky \& Tucker, 1998). For instance, happy people accept and recall their experiences in a more positive was than do unhappy people. Thus, happiness is said to be closely related to optimism (Lyubomirsky, Tkach, \& DiMatteo, 2006). Happy people expect more positive results from life than do unhappy people, and such expectations are said to have an overall positive effect on life. Diener (1984) suggested that happiness and unhappiness are based on inherently different underlying mechanisms, with different moderating effects. Diener (1984) replaced the notion of happiness with a new concept, subjective well-being, and differentiated between its cognitive components and affective components. Cognitive components refer to the degree of life satisfaction experienced, while affective components include positive affect among others. Such subjective wellbeing is closely related to behavioral intention. Chiu, Cheng, Huang, and Chen (2013) showed that satisfaction achieved via online social media use has positive effects on subjective well-being, on the intention to reuse the media platform, and on loyalty to it. Jamaludin, Sam, Sandal, and Adam (2016) reported that the perceived universalism of Norwegian international students had a positive effect on subjective wellbeing and that subjective well-being had a positive effect on the destination loyalty of international students. This finding shows that international students who are relatively stable and happy respond positively toward maintaining destination loyalty. Wang, Lin, and Liao (2010) stated that extraversion, agreeableness, and conscientiousness had positive effects on users' perceived pleasure with weblogs and that such perceived pleasure ultimately had a positive effect on behavioral intention. Based on these theoretical grounds, the present study predicted that subjective wellbeing evoked by serious leisure experiences would affect behavioral intention. The specific hypotheses of this study were:

H2: Subjective well-being has a significant effect on behavioral intention.

H2-1: Life satisfaction has a positive effect on behavioral intention

H2-2: Positive affect has a positive effect on behavioral intention

\section{Research Method}

\subsection{Participants and Procedure}

The present study employed the online research organization Macromill Embrain located in South Korea to conduct a survey. This study extracted samples from online panels by targeting users who had experience skiing at ski resorts. The online survey asked subjects whether they had skied during the previous ski season to extract an adequate number of responses. Only respondents who responded 'yes' were surveyed; those responding 'no' were excluded from the survey. These respondents underwent a scenario technique to arouse their memories of skiing. Respondents received a ski lesson at the ski area in the morning. Then, in the afternoon, they read a scenario instructing them to ski freely on the slopes. Next, they projected a shadow of themselves into a past skiing situation for one minute before participating in the survey. A final panel of 727 subjects participated in the survey. Respondents took the online survey, which covered the respondents' personality traits, subjective wellbeing, behavioral intentions, and demographic variables such as gender, age, and the frequency of skiing during a season. Respondents received a small financial reward in return for participating in the survey. The gender makeup 
of the respondents was 425 males $(58.5 \%)$ and 302 females $(41.5 \%)$. The ages included people in their $20 \mathrm{~s}(\mathrm{n}=213$; $29.3 \%), 30$ s (289; 39.8\%), 40s (155; 21.3\%), and 50s (70; $9.6 \%)$. With regard to the frequency of skiing in a season, $480(66.0 \%)$ respondents reported skiing 1-2 times, 173 (23.8\%) skied 3-4 times, $42(5.8 \%)$ skied 5-6 times, and 32 (4.4\%) respondents skied 7 or more times per season.

\subsection{Measures}

The main constructs examined in this study were measured on 5-point Likert scales using multiple items (except respondents' sex, age, and skiing frequency). Measures for all constructs are shown in Table 1.

Personality Traits: We measured personality traits by adopting a scale consisting of 17 items from Yoo and Gretzel (2011). Participants were asked to rate themselves in terms of the constructs of extraversion, openness to experience, conscientiousness, agreeableness, and neuroticism.

Subjective Well-being: This study developed and measured a scale of subjective well-being by modifying and supplementing scales used in previous studies (Diener, 1984). The scale involved assessing life satisfaction and positive affect in relation to leisure activities.

Behavioral Intention: This study used five items to assess behavioral intention (Kim \& Shim, 2017; Kim \& Shim, 2019; Chiu et al., 2013; Cho, 2019; Jamaludin et al., 2016; Wang et al., 2010): the extent to which the participant felt loyal to this ski resort, the intention to use this resort again, intention to offer positive word-of-mouth support for this resort, and intention to spend additional money to ski at this resort.

\subsection{Data Analysis}

We evaluated descriptive features and tested the reliability of the measurements using IBM SPSS statistic 23.0 software (IBM Corp., Armonk, NY, USA) and tested hypotheses using Amos 23.0. As a first analysis, we estimated the measurement validity of the model by conducting a confirmatory factor analysis. In the second analysis, we utilized structural equation modeling to test the hypothesized relationships.

\section{Results}

Table 2 shows descriptive statistics such as mean, standard deviation, and correlations among the variables. According to the analysis, we conducted confirmatory procedures to investigate the discriminant validity of measures. The reliability of the variables was investigated using Cronbach's alpha, and discriminant and convergent validity were tested based on average variance (AVE), composite reliability (CR), and correlation coefficients among the variables (Tables 2 and 3). The analysis of the relationship between positive
Table 1: Items Used to Measure Constructs

\begin{tabular}{|c|c|}
\hline Construct & Measurement Items \\
\hline \multirow{16}{*}{$\begin{array}{l}\text { Personality } \\
\text { Trait }\end{array}$} & $\begin{array}{l}\text { EXT } \\
\text { I always treat people warmly. }\end{array}$ \\
\hline & I am good with people. \\
\hline & I try to think of everything. \\
\hline & I tend to lead others well. \\
\hline & $\begin{array}{l}\text { OE } \\
\text { I am always thinking of something new }\end{array}$ \\
\hline & I enjoy cultural life and leisure. \\
\hline & I like new experiences. \\
\hline & $\begin{array}{l}\text { COS } \\
\text { I think I am competent. }\end{array}$ \\
\hline & I think I am good at dealing with people. \\
\hline & I am sure I can handle my duties. \\
\hline & $\begin{array}{l}\text { AGR } \\
\text { I am honest about everything. }\end{array}$ \\
\hline & I think of others before I think of myself. \\
\hline & I respect others and do not elevate myself. \\
\hline & \begin{tabular}{|l} 
NEU \\
I am always anxious.
\end{tabular} \\
\hline & I have a feeling of inferiority or compulsion. \\
\hline & I am sensitive to small slights. \\
\hline \multirow{10}{*}{$\begin{array}{l}\text { Subjective } \\
\text { Well-being }\end{array}$} & $\begin{array}{l}\text { LS } \\
\text { I am satisfied with my current leisure life. }\end{array}$ \\
\hline & Life through leisure seems to be very good. \\
\hline & $\begin{array}{l}\text { My leisure life has been the life I have } \\
\text { wanted so far. }\end{array}$ \\
\hline & I think my leisure life has developed ideally. \\
\hline & PA \\
\hline & I am interested in leisure. \\
\hline & I enjoy leisure. \\
\hline & $\begin{array}{l}\text { I have had good experiences with leisure } \\
\text { activities. }\end{array}$ \\
\hline & $\begin{array}{l}\text { I have positive memories of leisure } \\
\text { activities. }\end{array}$ \\
\hline & $\begin{array}{l}\text { I feel happy when I am involved in leisure } \\
\text { activities. }\end{array}$ \\
\hline \multirow{5}{*}{$\begin{array}{l}\text { Behavioral } \\
\text { Intention }\end{array}$} & $\begin{array}{l}\mathrm{BI} \\
\mathrm{I} \text { am willing to visit ski resort again. }\end{array}$ \\
\hline & $\begin{array}{l}\text { I will use ski resort again, even if it costs } \\
\text { extra money. }\end{array}$ \\
\hline & $\begin{array}{l}\text { I will talk about ski resort positively to } \\
\text { others. }\end{array}$ \\
\hline & $\begin{array}{l}\text { I will recommend ski resort to a friend or } \\
\text { acquaintance. }\end{array}$ \\
\hline & I will use ski resort first in the future. \\
\hline
\end{tabular}

Note. $\mathrm{EXT}=$ extraversion, $\mathrm{OE}=$ openness to experience, $\mathrm{COS}=$ conscientiousness, AGR = agreeableness, NEU = neuroticism. LS $=$ life satisfaction, $\mathrm{PA}=$ positive affect, $\mathrm{BI}=$ behavioral intention 
Table 2: Scale Means, Standard Deviations, and Correlations among Variables

\begin{tabular}{|c|c|c|c|c|c|c|c|c|}
\hline \multirow{2}{*}{ Variables } & \multicolumn{7}{|c|}{ Correlations } \\
\hline & $\mathbf{1}$ & $\mathbf{2}$ & $\mathbf{3}$ & $\mathbf{4}$ & $\mathbf{5}$ & $\mathbf{6}$ & $\mathbf{7}$ & $\mathbf{8}$ \\
\hline $1=\mathrm{EXT}$ & 1 & & & & & & & \\
\hline $2=\mathrm{OE}$ & .67 & 1 & & & & & & \\
\hline $3=\mathrm{COS}$ & .74 & .69 & 1 & & & & & \\
\hline $4=\mathrm{AGR}$ & .46 & .27 & .39 & 1 & & & & \\
\hline $5=\mathrm{NEU}$ & -.50 & -.41 & -.49 & -.39 & .1 & & & \\
\hline $6=\mathrm{LS}$ & .30 & .28 & .22 & .25 & -.14 & 1 & & \\
\hline $7=\mathrm{PA}$ & .33 & .31 & .22 & .23 & -.10 & .75 & .1 & \\
\hline $8=\mathrm{BI}$ & .35 & .33 & .26 & .30 & -.15 & .72 & .77 & 1 \\
\hline $\mathrm{M}$ & 3.5 & 3.6 & 3.5 & 3.5 & 2.9 & 3.5 & 3.8 & 3.6 \\
\hline $\mathrm{SD}$ & .60 & .65 & .59 & .62 & .68 & .71 & .64 & .69 \\
\hline
\end{tabular}

Note. $\mathrm{EXT}=$ extraversion, $\mathrm{OE}=$ openness to experience, COS = conscientiousness, $\mathrm{AGR}=$ agreeableness, $\mathrm{NEU}=$ neuroticism. $\mathrm{LS}=$ life satisfaction, $\mathrm{PA}=$ positive affect, $\mathrm{BI}=$ behavioral intention

Table 3: Results of the Confirmatory Factor and Reliability Analyses

\begin{tabular}{|c|c|c|c|c|c|c|}
\hline Variable & $\begin{array}{c}\text { Factor } \\
\text { loading }\end{array}$ & SE & $\begin{array}{c}\text { Critical } \\
\text { ratio }\end{array}$ & CR & AVE & $\boldsymbol{\alpha}$ \\
\hline EXT 1 & 1 & & & & & \\
EXT 2 & .910 & .071 & 12.88 & .824 & .542 & .741 \\
EXT 3 & 1.046 & .068 & 15.39 & & & \\
EXT 4 & .748 & .064 & 11.73 & & & \\
\hline OE 1 & 1 & & & & & \\
OE 2 & .866 & .070 & 12.67 & .768 & .524 & .693 \\
OE 3 & .966 & .074 & 13.10 & & & \\
\hline COS 1 & 1 & & & & & \\
COS 2 & 1.918 & .178 & 10.80 & .799 & .580 & .675 \\
COS 3 & 1.607 & .151 & 10.65 & & & \\
\hline AGR 1 & 1 & & & & & \\
AGR 2 & 1.498 & .139 & 10.76 & .756 & .512 & .624 \\
AGR 3 & 1.178 & .119 & 9.92 & & & \\
\hline NEU 1 & 1 & & & & & \\
NEU 2 & 1,093 & .072 & 15.11 & .802 & .576 & .739 \\
NEU 3 & 1.011 & .074 & 13.63 & & & \\
\hline LS 1 & 1 & & & & & \\
LS 2 & 1.126 & .051 & .22 .01 & .915 & .730 & .880 \\
LS 3 & 1.080 & .049 & 21.90 & & & \\
LS 4 & 1.123 & .047 & 24.07 & & & \\
\hline
\end{tabular}

\begin{tabular}{|c|c|c|c|c|c|c|}
\hline PA 1 & 1 & & & & & \\
PA 2 & .978 & .039 & 25.29 & & & \\
PA 3 & .992 & .038 & 25.85 & .943 & .768 & .905 \\
PA 4 & .992 & .039 & 25.43 & & & \\
PA 5 & 1.016 & .043 & 23.71 & & & \\
\hline BI 1 & 1 & & & & & \\
BI 2 & 1.085 & .040 & 27.39 & & & \\
BI 3 & 1.102 & .040 & 27.27 & .940 & .760 & .910 \\
BI 4 & 1.095 & .043 & 25.55 & & & \\
BI 5 & 1.041 & .016 & 22.58 & & & \\
\hline
\end{tabular}

Note. $\mathrm{EXT}=$ extraversion, $\mathrm{OE}=$ openness to experience, COS = conscientiousness, AGR = agreeableness, NEU = neuroticism. LS = life satisfaction, PA = positive affect, $\mathrm{BI}=$ behavioral intention

Table 4: Hypothesis Testing Results

\begin{tabular}{|c|c|c|c|c|c|}
\hline NO & Hypothesis & Estimate & SE & CR & P \\
\hline $1-1$ & EXT $\rightarrow$ LS & .416 & .116 & 3.588 & $<.001$ \\
\hline $1-2$ & OE $\rightarrow$ LS & .319 & .078 & 4.070 & $<.001$ \\
\hline $1-3$ & COS $\rightarrow$ LS & -.197 & .122 & -1.610 & .107 \\
\hline $1-4$ & AGR $\rightarrow$ LS & .308 & .085 & 3.643 & $<.001$ \\
\hline $1-5$ & NEU $\rightarrow$ LS & .077 & .052 & 1.469 & .142 \\
\hline $1-6$ & EXT $\rightarrow$ PA & .565 & .130 & 4.338 & $<.001$ \\
\hline $1-7$ & OE $\rightarrow$ PA & .401 & .084 & 4.758 & $<.001$ \\
\hline $1-8$ & COS $\rightarrow$ PA & -.259 & .133 & -1.944 & .052 \\
\hline $1-9$ & AGR $\rightarrow$ PA & .333 & .091 & 3.678 & $<.001$ \\
\hline $1-10$ & $\mathrm{NEU} \rightarrow \mathrm{PA}$ & .159 & .056 & 2.845 & .004 \\
\hline $2-1$ & LS $\rightarrow \mathrm{BI}$ & .397 & .045 & 8.747 & $<.001$ \\
\hline $2-2$ & $\mathrm{PA} \rightarrow \mathrm{BI}$ & .543 & .041 & 13.138 & $<.001$ \\
\hline
\end{tabular}

Note. $\mathrm{EXT}=$ extraversion, $\mathrm{OE}=$ openness to experience, $\mathrm{COS}=$ conscientiousness, $\mathrm{AGR}=$ agreeableness, $\mathrm{NEU}=$ neuroticism. LS = life satisfaction, PA = positive affect, $\mathrm{BI}=$ behavioral intention

affect and behavioral intention variables is not shown, as there was no clear correlation between the two variables. A $\chi 2$ difference analysis was performed using constrained and non-constrained models between the latent variables. The results of the analysis were statistically significant, ensuring discriminant validity. As shown in Table 3, the fit of the measurement model was satisfactory $(\chi 2=1307.64, \mathrm{df}=$ $377, \mathrm{p}<.001, \chi 2 / \mathrm{df}=3.469, \mathrm{CFI}=.916, \mathrm{TLI}=.903, \mathrm{RMR}$ 
$=.030$, and RMSEA $=.058$ ). The Cronbach's alpha values were $>.60$ for all constructs, which exceeded the threshold criterion of .60 for general acceptance of internal consistency reliability. A confirmatory factor analysis was carried out; the item factor loadings ranged from .70 to 2.0, and CR and AVE were above the threshold values of .70 and .50.

The goodness of fit of the analytical model was close to the standard value $(=2,132.00, \mathrm{df}=388, \mathrm{p}<.001, / \mathrm{df}=$ $5.495, \mathrm{CFI}=.842, \mathrm{TLI}=.823, \mathrm{RMR}=.104$, and $\mathrm{RMSEA}$ $=.079$; see Figure 1 and Table 4 ). A robust maximum likelihood estimation approach was utilized to generate this model. The hypothesis test results were as follows. First, extraversion positively influenced life satisfaction $(\beta E X T$ $\rightarrow \mathrm{LI}=.416, \mathrm{p}<.001)$, openness to experience positively influenced life satisfaction $(\beta \mathrm{OE} \rightarrow \mathrm{LI}=.319, \mathrm{p}<.001)$, and agreeableness positively influenced life satisfaction ( $\beta$ AGR $\rightarrow \mathrm{LI}=.308, \mathrm{p}<.001)$. Thus, H1-1, H1-2, and H1-4 were supported. Extraversion positively influenced positive affect $(\beta \mathrm{EXT} \rightarrow \mathrm{PA}=.565, \mathrm{p}<.001)$, openness to experience positively influenced positive affect $(\beta \mathrm{OE} \rightarrow \mathrm{PA}=.401, \mathrm{p}<$ $.001)$, and agreeableness positively influenced positive affect $(\beta A G R \rightarrow \mathrm{PA}=.333, \mathrm{p}<.001)$. Thus, H1-6, H1-7, and H1-9 were supported. In contrast to the established hypothesis, neuroticism enhanced positive affect $(\beta N E U \rightarrow \mathrm{PA}=.159$, $\mathrm{p}<.05)$. However, H1-3 (COS $\rightarrow$ LS), H1-5 (NEU $\rightarrow$ LS), and H1-8 (COS $\rightarrow$ PA) were not supported. Furthermore, life satisfaction positively influenced behavioral intention $(\beta \mathrm{LI} \rightarrow \mathrm{BI}=.397, \mathrm{p}<.001)$ and positive affect positively influenced behavioral intention $(\beta \mathrm{PA} \rightarrow \mathrm{BI}=.543, \mathrm{p}<.001)$. Thus, H2-1 and H2-2 were supported.

\section{Discussion}

The present study examined how the personality traits were related to serious leisure experiences and how they affected subjective well-being, specifically overall life satisfaction and positive affect. In addition, the study investigated how subjective well-being affected the behavioral intention to use the same leisure facilities again and the will to spread this information to acquaintances by positive word of mouth.

The results of the study were as follows. First, the personality traits had significant effects on subjective wellbeing during serious leisure experiences. The personality traits, specifically, extraversion, openness to experience, and agreeableness, had significantly positive effects on life satisfaction. In addition, extraversion, openness to experience, agreeableness, and neuroticism had significantly positive effects on affect. These results support those of DeNeve and Cooper (1998), Zhai et al. (2014), and Meléndez et al. (2019). Interestingly, neuroticism appeared to have a significant positive effect on positive affect. This result suggests that people who are high in neuroticism experience greater fun, pleasure, and happiness than do those who are low in neuroticism. In the past, blogging studies in online environments have shown that neuroticism has a positive

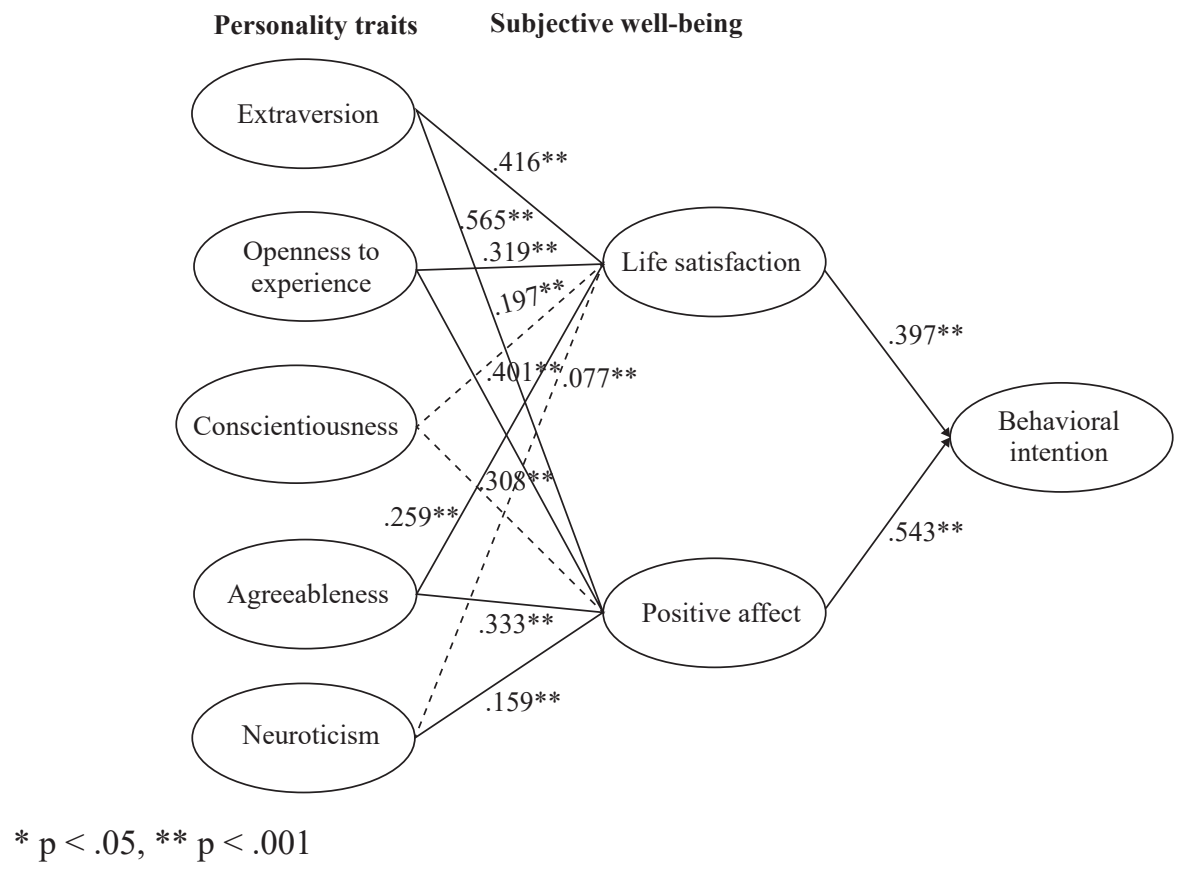

Figure 1: Research Model Verification Result 
effect on perceived enjoyment (Wang et al., 2010), and the same results have been found in serious leisure experiences in this study. Second, subjective well-being had a significant positive effect on behavioral intention. Both life satisfaction and positive affect had positive effects on behavioral intention. These results are in accord with the results of Chiu et al. (2013), Jamaludin et al. (2016), and Wang et al. (2010). In particular, positive affect had a greater effect on behavioral intention than on life satisfaction. This suggests that positive affect, an affective component, has a stronger expression in serious leisure experiences than does life satisfaction, a cognitive component.

The theoretical implications are numerous. First, previous studies of personality traits focused on the expression of personality traits in daily life leisure by targeting workers or elderly people (Anglim \& Grant, 2016; Gutiérrez et al., 2005; Hayes \& Joseph, 2003; Henning et al., 2017). However, the present study focused on the effects of the personality traits during serious leisure experiences. Unlike in previous studies, neuroticism was had a positive effect on well-being. Second, previous studies that established causal relationships between the personality traits and subjective well-being used regression analysis. To establish the effects of serious leisure experiences in more depth, the present study used a structural equation model to test these effects by targeting personality traits, subjective well-being, and behavioral intention.

The practical implications of our results are as follows. First, marketing managers at leisure companies could collect information revealing the personality traits of highly involved consumers of leisure products and services, such as frequent purchasers or seasonal pass holders, and use this information as the framework for building a customer relationship management (CRM) system for marketing. Furthermore, when using this marketing CRM, managers could take advantage of the fact that more neurotic, sensitive, and anxious users would likely feel greater stress relief because users higher in neuroticism are more likely to experience positive affect. Second, subjective wellbeing was established as significantly affecting behavioral intention. One-time users of leisure products or services must become regular users for the sustainable operation of a leisure business, making it necessary that users feel loyal to particular products. Operating regular offline meet-ups and encouraging communication activities through social media to increase the loyalty of these targeted customers are effective means for constantly reinforcing behavioral intention, as these methods are capable of maximizing extraversion, openness to experience, and agreeableness.

The limitations of this study and future research directions should be discussed. The present study was conducted with particular reference to skiing at a ski resort. Future research must establish the effects of personality traits for serious leisure experiences that are enjoyed during the green season as well, such as trekking, hiking, paragliding, and hang gliding. In addition, this study selected a pre-registered panel of users from an online research organization, choosing participants who had skied during the previous ski season. Future research needs to expand, so that the subsequent reallife effects of serious leisure experiences can be evaluated.

\section{References}

An, S., \& Zhang, J. (2019). The Effects of Chinese Coffee Shop Customers' Happiness on Continuous Usage Intention. Journal of Industrial Distribution \& Business, 10(3), 25-33. http:// dx.doi.org/10.13106/ijidb.2019.vol10.no3.25.

Anglim, J., \& Grant, S. (2016). Predicting psychological and subjective well-being from personality: Incremental prediction from 30 facets over the Big 5. Journal of Happiness Studies, 17(1), 59-80. http://doi.org/10.1007/s10902-014-9583-7.

Chiu, C. M., Cheng, H. L., Huang, H. Y., \& Chen, C. F. (2013). Exploring individuals' subjective well-being and loyalty towards social network sites from the perspective of network externalities: The Facebook case. International Journal of Information Management, 33(3), 539-552. http://doi. org/10.1016/j.ijinfomgt.2013.01.007.

Cho. S. H. (2019). The Effect of Mobile Tourism App Characteristics on Perceived Value, Satisfaction and Behavioral Intention. Journal of Industrial Distribution \& Business, 10(9), 45-52. http://dx.doi.org/10.13106/ijidb.2019.vol10.no9.45

Costa, P. T., \& Mac Crae, R. R. (1992). Neo personality inventoryrevised (NEO PI-R). Odessa, FL: Psychological Assessment Resources.

Csikszentmihalyi, M. (1990). Flow: The psychology of optimal experience. New York, NY: Harper \& Row.

DeNeve, K. M., \& Cooper, H. (1998). The happy personality: A meta-analysis of 137 personality traits and subjective well-being. Psychological Bulletin, 124(2), 197-229. http:// doi.org/10.1037/0033-2909.124.2.197.

Diener, E. (1984). Subjective well-being. Psychological Bulletin, 95(3), 542-575. https://doi.org/10.1037/0033-2909.95.3.542.

Diener, E., Oishi, S., \& Lucas, R. E. (2003). Personality, culture, and subjective well-being: Emotional and cognitive evaluations of life. Annual Review of Psychology, 54(1), 403-425. https:// doi.org/10.1146/annurev.psych.54.101601.145056.

Diener, E., Scollon, C. N., \& Lucas, R. E. (2009). The evolving concept of subjective well-being: The multifaceted nature of happiness. In Assessing Well-being (pp. 67-100). https:// doi.org/10.1007/978-90-481-2354-4_4.

Dirks, K. T., \& Ferrin, D. L. (2002). Trust in leadership: Metaanalytic findings and implications for research and practice. Journal of Applied Psychology, 87(4), 611-628. https:// doi.org/10.1037/0021-9010.87.4.611.

Gutiérrez, J.L. G., Jiménez, B. M., Hernández, E. G., \& Pcn, C. (2005). Personality and subjective well-being: Big five correlates and 
demographic variables. Personality and Individual Differences, 38(7), 1561-1569. https://doi.org/10.1016/j.paid.2004.09.015.

Hayes, N., \& Joseph, S. (2003). Big 5 correlates of three measures of subjective well-being. Personality and Individual Differences, 34(4), 723-727. https://doi.org/10.1016/S01918869(02)00057-0.

Heller, D., Watson, D., \& Ilies, R. (2004). The role of person versus situation in life satisfaction: A critical examination. Psychological Bulletin, 130(4), 574-600. https://doi.org/10.1037/00332909.130.4.574.

Henning, G., Hansson, I., Berg, A. I., Lindwall, M., \& Johansson, B. (2017). The role of personality for subjective well-being in the retirement transition-Comparing variable-and personoriented models. Personality and Individual Differences, 116(1), 385-392. https://doi.org/10.1016/j.paid.2017.05.017.

Hodgetts, R. M., \& Fountain, W. V. (1987). Modern Human Relations at Work. Instructor's Manual and Test Bank. New York, NY: The Dryden Press.

Jamaludin, N. L., Sam, D. L., Sandal, G. M., \& Adam, A. A. (2016). Personal values, subjective well-being and destination-loyalty intention of international students. Springerplus, 5(1), 720. https://doi.org/10.1186/s40064-016-2439-3.

John, O. P. (1990). The "Big Five" factor taxonomy: Dimensions of personality in the natural language and in questionnaires. In L. A. Pervin (Ed.), Handbook of personality: Theory and research (p. 66-100). New York, NY: The Guilford Press.

Judge, T. A., \& Bono, J. E. (2000). Five-factor model of personality and transformational leadership. Journal of Applied Psychology, 85(5), 751-765. https://doi.org/10.1037/0021-9010.85.5.751.

Kahneman, D., \& Krueger, A. B. (2006). Developments in the measurement of subjective well-being. Journal of Economic Perspectives, 20(1), 3-24. https://doi. org/10.1257/089533006776526030.

Kim, H. S., \& Shim, J. H. (2017). The effects of service qualities on customer satisfaction and behavioral intention in coffee shops. International Journal of Industrial Distribution \& Business, 8(5), 95-109. http://dx.doi.org/10.13106/ijidb.2017.vol8.no5.95.

Kim, H. S., \& Shim, J. H. (2019). The effects of quality factors on customer satisfaction, trust and behavioral intention in chicken restaurants. Journal of Industrial Distribution \& Business, 10(4), 43-56. http://dx.doi.org/10.13106/ijidb.2019.vol10.no4.43.

Larsen, R. J., \& Ketelaar, T. (1989). Extraversion, neuroticism and susceptibility to positive and negative mood induction procedures. Personality and Individual Differences, 10(12), 1221-1228. doi: 10.1016/0191-8869(89)90233-X

Lyubomirsky, S., \& Ross, L. (1997). Hedonic consequences of social comparison: A contrast of happy and unhappy people. Journal of Personality and Social Psychology, 73(6), 11411157. https://doi.org/10.1037/0022-3514.73.6.1141.

Lyubomirsky, S., Tkach, C., \& DiMatteo, M. R. (2006). What are the differences between happiness and self-esteem. Social
Indicators Research, 78(3), 363-404. https://doi.org/10.1007/ s11205-005-0213-y.

Lyubomirsky, S., \& Tucker, K. L. (1998). Implications of individual differences in subjective happiness for perceiving, interpreting, and thinking about life events. Motivation and Emotion, 22(2), 155-186. https://doi.org/10.1023/A:1021396422190.

McCrae, R. R., \& Costa, P. T. Jr. (1991). The NEO Personality Inventory: Using the five factor modeI in counseling. Journal of Counseling \& Development, 69(4), 367-372. https:// doi.org/10.1002/j.1556-6676.1991.tb01524.x.

.Meléndez, J. C., Satorres, E., Cujiño, M. A., \& Reyes, M. F. (2019). Big Five and psychological and subjective wellbeing in Colombian older adults. Archives of Gerontology and Geriatrics, 82(1), 88-93. https://doi.org/10.1016/j. archger.2019.01.016.

Richins, M. L. (2007). Consumption emotions. In H. N. J. Schifferstein \& P. Hekkert, (Eds.), Product experience: Perspectives on human-product interaction. Amsterdam, Netherlands: Elsevier Press.

Rusting, C. L., \& Larsen, R. J. (1997). Extraversion, neuroticism, and susceptibility to positive and negative affect: A test of two theoretical models. Personality and Individual Differences, 22(5), 607-612. doi: 10.1016/S0191-8869(96)00246-2

Ryan, R. M., \& Deci, E. L. (2001). On happiness and human potentials: A review of research on hedonic and eudaimonic well-being. Annual Review of Psychology, 52(1), 141-166. https://doi.org/10.1146/annurev.psych.52.1.141.

Schimmack, U., Radhakrishnan, P., Oishi, S., Dzokoto, V., \& Ahadi, S. (2002). Culture, personality, and subjective wellbeing: Integrating process models of life satisfaction. Journal of Personality and Social Psychology, 82(4), 582-593. https:// doi.org/10.1037/0022-3514.82.4.582.

Stebbins, R. A. (1982). Serious leisure: A conceptual statement. Pacific Sociological Review, 25(2), 251-272. https:// doi.org/10.2307/1388726.

Stebbins, R. A. (1992). Amateurs, professionals, and serious leisure. Montreal, QC: McGill-Queen's Press-MQUP.

Tourism \& Leisure Industry Skill Council of the Republic of Korea. (2018). Report on the Industrial Manpower in Tourism and Leisure 2018. Retrieved from http://koreacasino.or.kr/e-book/ ecatalog5.jsp?Dir=81.

Unger, L. S., \& Kernan, J. B. (1983). On the meaning of leisure: An investigation of some determinants of the subjective experience. Journal of Consumer Research, 9(4), 381-392. https://doi.org/10.1086/208932.

Uziel, L. (2006). The extraverted and the neurotic glasses are of different colors. Personality and Individual Differences, 41(4), 745-754. https://doi.org/10.1016/j.paid.2006.03.011.

Wang, Y. S., Lin, H. H., \& Liao, Y. W. (2010). Investigating the individual difference antecedents of perceived enjoyment in students' use of blogging. British Journal of Educational 
Technology, 43(1), 139-152. https://doi.org/10.1111/j.14678535.2010.01151.x.

Yoo, K. H., \& Gretzel, U. (2011). Influence of personality on travel-related consumer-generated media creation. Computers in Human Behavior, 27(2), 609-621. https://doi.org/10.1016/j. chb.2010.05.002.

Zhai, Q., Willis, M., O’shea, B., Zhai, Y., \& Yang, Y. (2014). Big Five personality traits, job satisfaction and subjective wellbeing in China. International Journal of Psychology, 48(6), 10991108. https://doi.org/10.1080/00207594.2012.732700.

Oswald, A. (1997). Happiness and economic performance. Economic Journal Royal Economic Society, 107(445), 1815-1831.

Paldam, M. (2001). Social capital: One or many? Definition and measurement. Journal of Economic Perspectives, 14, 629-653.

Paxton, P. (1999). Is social capital declining in the United States? A multiple indicator assessment. American Journal of Sociology, $105,88-127$.

Pichler, F. (2006). Subjective quality of life of young Europeans: Feeling happy but who knows why? Social Indicators Research, $75,419-444$.

Powdthavee, N. (2009). Putting a price tag on friends, relatives, and neighbours: Using surveys of life satisfaction to value social relationships. The Journal of Socio-Economics, 37(4), 1459-1480.
Putnam, R. (2000). Bowling alone: The collapse and revival of American Community. New York, NY: Simon \& Schuster.

Ram, R. (2010). Social capital and happiness: Additional crosscountry evidence. Journal of Happiness Studies, 11, 409-418.

Rodrik, D. (1998). Where did all the growth go? External shocks, social conflict, and growth collapses (NBER Working Paper No. 6350). National Bureau of Economic Research, Cambridge.

Shin, H. K., \& Jo, I. S. (2015). A study on the subjective happiness and social capital. Journal of the Korean Housing Association, 26(3), 99-108.

van Oorschot, W., Arts, W., \& Gelissen, J. (2006). Social capital in Europe: Measurement and social and regional distribution of a multifaceted phenomenon. Acta Sociologica, 49(2), 149-167.

Woolcock, M., \& Narayan, D. (2000). Social capital: Implications for development theory, research, and policy. World Bank Research Observer, 15(2), 1-49.

Smelser, N., \& Swedberg, R. (1994). The handbook of economic sociology (Eds.). Princeton, NJ: Princeton University Press.

Winkelmann, R. (2009). Unemployment, social capital, and subjective well-being. Journal of Happiness Studies, 10(4), 421-430.

Zak, P., \& Knack, S. (2001). Trust and growth. The Economic Journal, 111, 295-321. 
